\title{
Komisi Ombudsman Nasional: Problem dan Prospek
}

\author{
Susi Dwi Harijanti
}

\begin{abstract}
Having regard to the failure of the existing complaint system, the Wahid's administration govemment has formed a new institution in an effort to cover the weaknesses of the existing supervisory institutions. The new institution is the National Ombudsman Commission, which was established through the Presidential Decree Number 44 of 2000. Within two years of its operation, the Ombudsman has received more than 1, $723 \mathrm{com}$ plaints including those regarding the executive government officer as well as the judiciary. This may indicate that people put high expectation on this new Commission. However, apart from the impressive number of received complaints, there are some significant problems faced by this Commission that embrace, legal, politics as well as social impediments. This article examines those problems and proposes some reforms.
\end{abstract}

\section{Pendahuluan}

Tahun 2000, tepatnya 20 Maret Pemerintah telah mendirikan suatu institusi baru yang dikenal dengan nama Komisi Ombudsman Nasional (selanjutnya dalam tulisan ini disingkat KON) melalui Keputusan Presiden Nomor 44 Tahun 2000 (selanjutnya disingkat Keppres): Pendirian ini dapat dipandang sebagai salah satu upaya yang dilakukan Pemerintah dalam mewujudkan, atau setidaknya memperbaiki kualitas pelayanan kepada masyarakat dalam proses penyelenggaraan negara.

Harus diakui bahwa setidak-tidaknya dalam tiga dasa warsa terakhir, kualitas perlindungan negara terhadap masyarakat menjadi semakin turun. Dalam Seminar tentang Good Governance yang diselenggarakan oleh KON, Sir Brian Elwood mengemukakan beberapa alasan mengapa masyarakat makin menunjukkan keprihatinannya terhadap administrasi negara. Alasan-alasan itu mencakup: adanya peningkatan dominasi birokrasi, terutama setelah 1930-an, yang pada gilirannya mengalahkan peran warga negara, timbulnya ketidakseimbangan kekuasaan antar warga negara, ketidaktanggapan serta ketidakefisiensian administrasi negara, ${ }^{{ }^{\prime}}$ dan pelayanan yang dilakukan oleh administrasi

'Sir Brian Elwood, Speech Notes disampaikan pada Seminar Good Govemance (Jakarta: Komisi Ombudsman Nasional, 2000), him 4. 
Dalam konteks Indonesia, hal ini dibuktikan dengan makin banyaknya kelutian ataupun gugatan yang ditujukan kepada pemerintah yang meliputi hampir seluruh cabang-cabang pemerintahan, baik legislatif, eksekutif maupun badan peradilan. Kondisi semacam ini makin diperburuk oleh ketidakmampuan berbagai pranata dan institusi yang ada untuk menyelesaikan keluhan ataupun gugatan tersebut.

Secara umum, pengawasan terhadap pemerintah dapat dilakukan melalui pengawasan internal yang melibatkan institusi internal, misalnya di lingkungan administrasi negara dikenal dengan nama inspektorat jenderal (itjen), pengawasan melekat (waskat), ataupun melalui Badan Pemeriksa Keuangan dan Pembangunan (BPKP). Sedangkan pengawasan ekstemal dapat dilakukan melalui lembaga peradilan ataupun lembaga-lembaga negara lainnya, misalnya Badan Pemeriksa Keuangan.

Berbelit-belitnya prosedur yang harus ditempuh yang acapkali diperparah dengan arogansi birokrasi, lamanya waktu serta tingginya biaya yang harus dikeluarkan oleh masyarakat, merupakan beberapa alasan yang melatarbelakangi perlunya suatu institusi baru guna menampung dan menyelesaikan keluhan-keluhan masyarakat tersebut.

\section{Problem Birokrasi dan Perlunya Pengawasan}

Tahun 1887 oleh beberapa kalangan akademisi Amerika dipandang sebagai tahun kelahiran administrative state yang antara lain ditandai dengan dipublikasikannya karya Woodrow Wilson yang berjudul "The Study of Administration" serta didirikannya Komisi Negara Bagian untuk Perdagangan, yang dapat dikatakan sebagai bentuk dasar badan , regulator independen Amerika untuk abad ke20. ${ }^{2}$ Perkembangan selanjutnya menunjukkan makin banyaknya badan semacam ini didirikan untuk menjalankan fungsi-fungsi tertentu. Misalnya fungsi pengaturan dan pengawasan terhadap lingkungan, makanan, dan obatobatan.

Fenomena di atas tidak terlepas dari dianutnya paham negara kesejahteraan (welfare state atau negara hukum dalam arti materiil) yang mengandung esensi bahwa negara atau pemerintah memikul tanggung jawab dan kewajiban untuk mewujudkan dan menjamin kesejahteraan umum. Peran pemerintah menjadi semakin besar dan kuat yang dibuktikan dengan makin banyaknya campur tangan pemerintah hampir di semua segi kehidupan masyarakat. Bidang-bidang kehidupan yang tadinya lepas dari campur tangan pemerintah, misalnya penetapan upah pekerja, menjadi bidang yang menghendaki campur tangan pemerintah. Besar kecilnya upah tidak lagi semata-mata digantungkan pada kehendak pengusaha atau pemilik modal, melainkan ditentukan berdasarkan kebijakan pemerintah. Hal ini dilakukan semata-mata untuk menjamin bahwa pekerja mendapatkan haknya secara wajar.

Akibat makin banyaknya fungsi sosial yang harus dilakukan oleh pemerintah, maka berakibat pada makin bertambahnya jumlah administrasi negara, termasuk pulakelembagaannya. Aturan-

${ }^{2}$ Herman Belz, "A living constitution or fundamental law?: American Constitutionalism in Historical Perspective. "http://uww.constitution.org.cmthelz/cf.htm. him 1. 
aturan yang mengatur hubungan tata kerja antar lembaga-lembaga administrasi negara makin bersifat kompleks. Sementara itu dari perspektif warga negara, pertambahan ini berarti birokrasi menjadi lebih panjang dan berbelit-belit.

Pertambahan ini mengakibatkan pula perubahan pola interaksi antara administrasi negara dan warga negara yang ditandai oleh beberapa karakteristik, antara lain: ${ }^{3}$

1. Ketiadaan aturan permainan serta prosedur yang jelas;

2. Adanya jargon-jargon yang bersifat teknis yang acapkali hanya dimengerti oleh kalangan tertentu;

3. Adanya kepercayaan terhadap kebiasaan yang telah lama dilaksanakan, yang pada gilirannya menghambat munculnya eksperimen serta kreativitas;

4. Peningkatan standar operasional yang bersifat rutin yang ternyata tidak responsif terhadap permasalahan perorangan; dan

5. Adanya tendensi bahwa administrasi negara lebih mengutamakan kepentingannya daripada kepentingan masyarakat.

Selain itü, peran pemerintah atau negara yang menguat secara teoritis didukung oleh teori positif dalam hukum administrasi negara yang diterjemahkan sebagai ketentuanketentuan hukum administrasi negara yang mengatur tata cara pemerintah turut serta dalam pergaulan masyarakat (mencampuri urusan masyarakat). ${ }^{4}$ Dalam melaksanakan proses penyelenggaraan pemerintahan tersebut, administrasi negara dilengkapi berbagai kewenangan untuk melakukan atau tidak melakukan suatu tindakan yang diatur dalam berbagai peraturan perundangundangan.Namun dalam prakteknya, di satu sisj administrasi negara seringkali dihadapkan pada situasi di mana peraturan perundangundangan tidak mengatur secara tegas, sedangkan di sisi lain, suatu tindakan harus segera diambil untuk memecahkan masalah. Guna menghindari kekosongan semacam itu, maka administrasi negara dilengkapi kewenangan untuk melakukan diskresi.

Berkenaan dengan penggunaan diskresi ini, Dicey telah mengingatkan bahwa di mana ada diskresi, di situ terbuka peluang untuk terjadinya kesewenang-wenangan. ${ }^{5}$ Montesquieu juga telah mensinyalir watak hitam kekuasaan dengan menyebutkan kekuasaan itu mengandung sifat tamak. ${ }^{6}$ Belz menambahkan bahwa masalah-masalah yang berkaitan dengan birokrasi sebetulnya merupakan masalah klasik antara diskresi melawan peraturan perundang-undangan. Lengkapnya Belz menyatakan:?

"From constitutionalist point of view the problem of bureaucracy arises not from the mere fact of hierarchically or-

${ }^{3}$ Alan J. Wayner (ed.), Executive Ombudsmen in the United States (Berkeley: Institute of Govemmental Studies, 1973), hlm 4.

${ }^{4}$ Bagir Manan, Lembaga Kepresidenan (Yogyakarta: Penerbit Gama Media bekerja sama dengan Pusat Studi Hukum Universitas Islam Indonesia, 1999), hlm 13-14.

${ }^{5}$ Donald C. Rowat, The Ombudsman Plan (Toronto: The Canadian Publisher, 1973), hlm 46.

${ }^{6}$ Bagir Manan, "Fungsi Ombudsman," makalah disampaikan pada Workshop Ombudsman (Surabaya: Universitas Airlangga, 2000), hlm 1

${ }^{7}$ Belz, op.cit., hlm 6 . 
ganized institutions performing specialized functions, but from the exercise of unauthorized political and governmental power by administrative bodies. The problem of bureaucracy, in other words, is the ancient problem of discretion versus law."

Berangkat dari beragam akibat yang ditimbulkan karena makin besarnya peran birokrasi, muncul satu pertanyaan mendasar yakni apakah negara mempunyai kewajiban konstitusional menyediakan mekanisme untuk perbaikan dan penyelesaian aduan atau keluhan ${ }^{8}$ Bahkan secara tegas Lewis dan Birkinshaw menyatakan apakah penyelesaian keluhan (grievance redress) merupakan tanggung jawab negara. ${ }^{9}$

\section{Mengapa dan Apakah Ombudsman itu?}

\section{Kelemahan Mekanisme dan Institusi yang Ada Saat ini}

Dalam salah satu tulisannya Bagir Manan menyatakan bahwa salah satu ciri penting negara demokrasi berdasarkan atas hukum adalah tersedianya jaminan bagi setiap orang untuk "memperkarakan" pemerintah atau negara yang dianggap melakukan tindakan yang merugikan baik secara material maupun immaterial. ${ }^{10}$ Selanjutnya dikatakan bahwa memperkarakan di sini ditafsirkan dalam arti luas yang meliputi penyampaian keluhan, keberatan, bahkan sampai pada tingkat memperkarakan secara hukum. Pada dasamya jaminan dan hak tersebut mempunyai dua arti penting, yakni: ${ }^{11}$ Pertama, secara preventif, memberikan dorongan yaing kuat kepada pemerintah atau negara agar bertindak lebih hati-hati dalam melakukan segala hal yang berkenaan dengan proses penyelenggaraan pemerintahan. Kedua, secara represif, merupakan mekanisme pemulihan yang diberikan kepada perorangan ataupun masyarakat yang hak-haknya terlanggar oleh pemerintah atau negara.

Berdasarkan paparan di atas, dapat secara tegas dikatakan bahwa negara memiliki kewajiban konstitusional untuk mengadakan berbagai pranata dan mekanisme penyampaian dan perbaikan aduan masyarakat. Lewis dan Birkinshaw bahkan menandaskah bahwa "an effective system of redress and justice is a state responsibility and irreducible state responsibility. ${ }^{.12}$

Secara umum, pengawasan terhadap pemerintah dapat dilakukan melalui berbagai institusi serta mekanisme yang ada. Dilihat dari sifat pengawasan, misalnya pengawasan politik dilakukan oleh DPR, sedangkan pengawasan secara hukum dilakukan oleh badan peradilan. Dari sudut kelembagaan, mekanisme intemal dilaksanakan misalnya melalui Kotak Pos 5000, Waskat, dan inspektorat jenderal, sedangkan post control dilakukan oleh lembaga peradilan. Artinya seseorang yang hendak menyampaikan

\footnotetext{
${ }^{8}$ Alan J. Wayner (ed), op.cit., hlm 9.

${ }^{9}$ Norman Lewis dan Patrick Birkinshaw, When Citizens Complain: Reforming Justice and Administration (Buckingham: Open University Press, 1993), hlm 17.

${ }^{10}$ Bagir Manan, loc. cit.

11 lbid.

${ }^{12}$ Norman Lewis dan Patrick Birkinshaw, op.cit., hlm 19.
} 
keluhan atau bahkan melakukan gugatan terhadap pemerintah atau negara dapat menggunakan saluran-saluran di atas. ${ }^{13}$

Pitihan untuk menyelesaikan melalui jalur hukum dapat dilakukan melalui pemeriksaan melalui pengadilan yang akan menggunakan dasar tuntutan seperti di antaranya, pengujian (judicial review), perbuatan melawan hukum, penyalahgunaan wewenang, kesewenangwenangan..$^{14}$ Selain itu penyelesaian dapat pula menggunakan arbitrase; mediasi, dan konsiliasi. Pilihan-pilihan lain juga terbuka untuk digunakan, misalnya penyelesaian melaiui peradilañ semu.

Namun, kenyataan menunjukkan bahwa pilihan-pilihan yang tersedia seringkali tidak memuaskan dan tidak mencapai tujuan yang diharapkan. Penyelesaian melalui jalur pengadilan, misainya, mengandung beberapa kelemahan utama, antara lain membutuhkan waktu yang panjang, lambat, dan mahal: Kelemahan itu terjadi karena banyaknya jumlah perkara yang harus ditangani oleh pengadilan, yang pada gilirannya akan memperlambat proses pemeriksaan. Panjang atau lamanya waktu disebabkan antara lain oleh rumitnya proses beracara di pengadilan, atau sebabsebab lain. Karena proses yang ditempuh memakan waktu yang lama, maka tidak mengherankan biaya yang harus dikeluarkan juga menjadi tidak sedikit jumlahnya. Singkatnya, masalah-masalah di atas timbul karena tidak adanya simplifikasi ketentuan beracara serta lemahnya management cases.
Penggunaan mekanisme internal juga acapkali tidak memberikan hasil yang memadai karena berbagai kendala, misalnya adanya resistensi yang kuat dari institusi yang dikeluhkan, tidak adanya sistem pelaporan kepada publik secara berkala yang menggambarkan secara jelas langkah-langkah yang telah ditempuh dalam menangani pengaduan, dan lain-lain. Dalam banyak kasus korupsi, mekanisme internal seringkali menggunakan penyelesaian dengan mengharuskan si pelaku untuk mengembalikan uang yang diduga digunakan. Setelah itu, kasus dinyatakan selesai, tanpa meneruskan ke lembaga penyidik dan pengadilan: Artinya, tindak pidana korupsi dinyatakan tidak ada begitu uang dikembalikan.

Dalam pada itu penyampaian keluhan ataupun pengaduan melalui lembaga politik, misalnya DPR, juga tidak membuahkan hasil yang diharapkan. Meskipun lembaga ini dapat menampung dan menangani keluhan masyarakat terhadap sikap tindak administrasi negara melalui fungsi pengawasan, namun dalam kenyataannya lembaga politik semacam ini memiliki keterbatasan atau kendala yang bersifat substantial. Dalam pandangan masyarakat, anggota-anggota DPR bukanlah merupakan orang yang netral. Hal ini disebabkan adanya pertalian atau hubungan yang kuat antara anggota DPR dengan partai politik. Selain itu, para anggota DPR memiliki beban kerja yang tidak kalah pentingnya yang berkaitan dengan fungsi legislastif:

${ }^{13}$ Uraian mengenai berbagai lembaga yang pernah menangani masalah aduan atau dugaan korupsi dapat dilihat pada lbrahim Assegaf, "Legends of the Fall: An Institutional Analysis of Indonesian Law Enforcement Agencies Combating Corruption" dalam Tim Lindsey dan Howard Dick (eds.), Comption in Asia: Rethinking the Govemance Paradigm (Sydney: The Federation Press, 2002), hlm 127-146.

${ }^{14}$ Bagir Manan, op.cit., him 2. 
Pada suatu negarayang menjalankản sistem pemerintahan' parlementer, khususnya di mana terdapat dua partai politik terbesar, eksekutif cenderung mendominasi parlemen dan mempertahankan tradisi menjaga kerahasiaan administrasi (administrative secrecy). ${ }^{15}$ Akibatnya, akan sangat sulit menyoroti suatu perkara yang berkaitan dengan maladministrasi. Perorangan atau bahkan anggota parlemen sekalipun akan sangat sulit untuk mengetahui apakah yang sebenamya terjadi.

Rowat juga menegaskan bahwa dalam suatu negara yang menjalankan ajaran pemisahan kekuasaan atau sistem multi partai sekalipun, di mana eksekutif tidak terlalu dominan, biasanya lembaga legislatif tidak mempunyai suatu komisi ataupun mekanisme khusus untuk menangani aduan di bidang administrasi negara yang dilengkapi dengan kewenangan untuk mendapatkan fakta-fakta, bukti-bukti, atau bahkan jika ketidakadilan ditemukan dapat mengajukan usul perbaikan yang memadai. ${ }^{16}$

Merujuk pada kelemahan-kelemahan dari lembaga serta mekanisme yang ada saat ini, maka timbul gagasan mengenai pentingnya untuk membentuk suatu institusi baru yang dapat menutupi kelemahan-kelemahan tersebut. Yakni suatu institusi yang bersifat independen, tidak memihak, dapat dipercaya, dapat diakses dengan mudah yang beroperasi melalui prosedur yang bersifat informal, serta berada di antara intemal control dan post control.

Guna menjawab tuntutan tersebut, pilihan jatuh pada pembentukan ombudsman sebagai sebuah upaya untuk memperluas pilihan bagi masyarakat untuk melindungi hak atau kepentingan dari tindakan pemerintah atau negara yang merugikan, pengurangan atau peniadaan hak secara sewenangwenang, tidak wajar, tidak pantas, atau tidak adil. ${ }^{17}$ Tegasnya, kehadiran ombudsman bukan sebagai alternatif kelembagaan, melainkan sebagai suatu kebutuhan. ${ }^{18}$

Secara ringkas terdapat beberapa keuntungan menggunákan ombudsman sebagai kanal untuk menampung dan menyelesaikan aduan atau pun keluhan masyarakat. Kelebihan-kelebihan itu antara lain, mencakup:

\section{a. Kelembagaan dan keanggotaan}

Ombudsman merupakan lembaga yang bersifat mandiri dan independen, terlepas dari pengaruh badan legislatif maupun eksekutif. Meskipun dapat dibentuk baik oleh partemen atau pun eksekutif, namun kedua badan tersebut tidak dapat mempengaruhi atau memberikan tekanan-tekanan tertentu terhadap ombudsman. Hal ini didukung oleh kenyataan bahwa anggota-anggota ombudsman adalah orangorang non-partisan dan tidak memegang rangkap jabatan sehingga diharapkan terbebas dari vested interest tertentu.

\section{b. Fleksibilitas dan Informalitas Prosedur}

Berbeda dengan proses beracara di pengadilan, prosedur penyampaian dan pemeriksaan aduan lebih bersifat informal di

\footnotetext{
${ }^{15}$ Donald C. Rowat, op.cit., him 48.

${ }^{16} /$ bid.

${ }^{17}$ Bagir Manan, op.cit., hlm 3.

${ }^{18} \mathrm{lbid}$.
} 
mana aduan dapat disampaikan melalui syaratsyarat dan tata cara yang lebih mudah. Pengadu dapat menyampaikan sendiri tanpa memerlukan bantuan pengacara, bahkan dapat melalui media telekomunikasi (telepon, fax) dan intemet (email). Atau dengan kata lain, akses ke ombudsman lebih mudah dibandingkan dengan pengadilan. Selain itu, ombudsman tidak mengenakan pungutan. Akibatnya, biaya yang dikeluarkan relatif tidak banyak dibandingkan dengan penyelesaian lewat jalur pengadilan.

\section{Ombudsman: Asal Mula dan Perkembangannya}

Lembaga semacam ombudsman sebenamya telah dikenal sejak lama dan telah dipraktekkan di berbagai wilayah di belahan bumi ini kurang lebih 4000 tahun lalu. ${ }^{19}$ Pada masa Kerajaan. Mesir, misalnya, Raja menggunakan pegawai-pegawai yang menangani keluhan yang ditempatkan di lingkungan peradilan. Selain itu, pada masa Republik Romawi, ada pula petugas yang mengawasi segala tindakan administrasi negara dan sekaligus pula menampung keluhan yang berkaitan dengan maladministrasi. Di belahan Asiä, tepatnya, di Cina, raja-raja pada masa Dinasti Han dikenal dengan istilah the Control Yuan. ${ }^{20}$ Namun, Elwood menyatakan bahwa Yuan kontrol lebih dimaksudkan sebagai metoda melakukan pengawasan daripada sebagai alat yang digunakan untuk memeriksa sikap tindak administrasi negara. ${ }^{21}$

Selanjutnya, Wiegand menjelaskan bahwa istilah ombudsman berasal dari praktek yang dilakukan di masa abad pertengahan oleh suku bangsa di Jerman. Pada masa itu hanya terdapat dua jenis hukuman bagi orang-orang yang melanggar hukum, yakni dihukum mati atau didenda. Bagi orang yang dijatuhi denda, keluarga terpidana diharuskan membayar denda tersebut kepada keluarga korban. Guna menghindari konflik lanjutan, maka dipandang perlu untuk menghadirkan pihak ketiga yang bersifat netral yang bertugas untuk mengambil uang denda dan kemudian mengantarkannya ke pihak korban. Ketika pihak ketiga itu datang ke rumah korban seraya berteriak memberitahukan maksudnya, maka orang di rumah korban menjawab dan memberitahukan keluarga lainnya: "dia adalah orang yang membawa denda yakni ombudsman." "Om" berart "tentang atau hal", sedangkan "bud" berasal dari "menawarkan". Jadi ombudsman adalah seseorang yang datang untuk menawarkan. Dalam perkembangannya istilah ombudsman menunjuk pada segala bentuk agen, perwakilan ataupun perantara. ${ }^{2}$

Sebaliknya, Satyanand berpendapat bahwa istillah ombudsman berasal dari Skandinavia yang berarti orang yang dapat dipercaya. Kata "man" diambil dari bahasa Swedia (bahasa Norse lama yakni "umbodhsmadr") yang tidak secara spesifik menunjuk pada jenis kelamin laki-laki.23

${ }^{19}$ Sir Brian Elwood, op.cit., hlm 5.

${ }^{20}$ Shirley A. Wiegand, "A Just and Lasting Peace: Supplanting Mediation with the Ombuds Model", Artikel dalam Ohio State Joumal on Dispute Resolution. No. 12. Tahun 1996, hlm 97. http://www.lexis.com

${ }^{21}$ Sir Brian Elwood, loc. cit.

22.Shirley A. Wiegand, loc.cit.

${ }^{23}$ Judge Satya Anand, "Operation of Ombudsman Concept in a Variety of Constitutional Settings," Makalah disampaikan pada Konferensi Ombudsman Asia Ke-4 (Teheran, 1999), hlm 2. 
Swedia yang pertama kali mendirikan ombudsman sebagaimana yang dikenal saat ini pada 1809 , bersamaan dengan ditetapkannya konstitusi baru yang lebih demokratis oleh Parlemen. Saat itu Parlemen Swedia membentuk apa yang dinamakan sebagai Justitieombudsman. Sebelumnya pada 1713, Raja Swedia menunjuk seseorang untuk menyelidiki keluhan masyarakat terhadap pegawai-pegawai kerajaan. ${ }^{24}$

Lebih dari seratus tahun kemudian Finlandia mengikuti jejak Swedia dengan mendirikan ombudsman pada 1919 dan Denmark pada 1955. Setelah itu, ombudsman menyebar ke berbagai negara dengan sangat cepat. New Zealand merupakan negara berbahasa Inggris pertama dan sekaligus negara Commonwealth pertama yang mendirikan ombudsman pada 1962. Tanzania pada 1966, beberapa provinsi di Kanada mulai 1967, Inggris pada 1967, dan Mauritius pada 1968.

Selama kurun waktu 1970-an dan 1980an ombudsman juga didirikan di beberapa negara, antara lain Australia (Federal Ombudsman) 1976. Perubahan pemerintahan dari absolut ke sistem yang lebih demokratis berdampak pula pada pendirian ombudsman. Fenomena ini dijumpai di belahan Eropa Selatan (akhir 1980-an), Amerika Latin (selama 1980-an), serta kawasan Eropa Tengah dan Timur menyusul runtuhnya dominasi Uni So- viet. Jika pada 1983, terdapat kurang lebih 21 ombudsman pada tingkat nasional, maka di tahun 1997 terjadi kenaikan yang sangat mengesankan, yakni menjadi 87 negara yang memiliki ombudsman baik di tingkat nasional, provinsi, atau bahkan kota. ${ }^{25}$ Di tingkat supranasional, European Union pada tanggal 1 September 1995 melalui the Treaty on European Union (Maastricht Treaty) telah membentuk the European Ombudsman untuk mengawasi kegiatan berbagai institusi dan badan di lingkungan European Union. Kenyataan di atas menunjukkan beberapa hal: 26

1. Ombudsman tidak terkait dengan sistem hukum tertentu. Ombudsman ada di negara-negara dengan sistem hukum Anglo-Saxon (Inggris, Australia, Kanada, dan lain-lain) dan Eropa Kontinental (Indonesia, Belanda, dan sebagainya).

2. Ombudsman tidak terkait dengan sistem pemerintahan tertentu. Negara-negara dengan sistem Parlementer (Australia, New Zealand), Campuran (Perancis) dan Presidensial (Filipina, Indonesia) mempunyai ombudsman.

3. Ombudsman tidak terkait dengan bentuk negara (federal dan kesatuan) serta bentuk pemerintahan (kerajaan dan republik). Ombudsman dijumpai di Aus-

${ }^{24}$ Paparan mengenai Ombudsman Swedia lebih lanjut dapat dilihat antara lain pada Frank Stacey, $\mathrm{Om}$ budsman Compared (Oxford: Clarendon Press, 1978), hlm 1-17. Donald C. Rowat, The Ombudsman: Citizen's Defender (London: George Allen \& Unwin, 1965), hlm 17-51. Walter Gellhorn, Ombudsmen and Others: Citizens' Protector in Nine Countries (Cambridge, Massachusetts: Harvard University Press, 1966), hlm 194-255.

${ }^{25}$ Linda C. Reif (ed.), The Intemational Ombudsman Anthology (The Hague: Kluwer Law Intemational, 1999), hlm xojv.

${ }^{23}$ Bagir Manan, op.cit., hlm 2. 
tralia dan Kanada (Federal); Korea dan Iran (Kesatuan); Inggris, Belanda, dan Swedia (Kerajaan); serta Indonesia, Filipina, dan lain-lain (Republik).

4. Ombudsman tidak terkait dengan sistem idiologi tertentu. Negara-negara komunis dan non-komunis memiliki ombudsman, misal Vietnam.

Selain itu pembentukan ombudsman di negara-negara di luar Swedia juga menunjukkan bahwa tidak terdapat satu model ombudsman yang seragam yang berlaku di semua negara. Hal ini dapat dimengerti karena transplantasi lembaga (institutional transplant) sebagaimana legal transplant senantiasa menyesuaikan diri dengan faktor-faktor yang ada di suatu negara atau masyarakat tertentu. Misalnya, faktor ekonomi, sosial dan politik, kebudayaan, termasuk hubungannya dengan bentuk-bentuk lain dari lembaga pengawas administrasi negara. Mengamati perkembangan yang terjadi beberapa ahli ombudsman mengkategorikan ombudsman dalam beberapa tipe atau jenis:27 a. Tipe klasik (classical ombudsman) dengan menunjuk pada ombudsman Swedia. Umumnya ombudsman tipe ini keanggotaannya ditunjuk dan ditetapkan oleh parlemen dan berkewajiban memberikan laporan kepada parlemen.

b. Tipe ombudsman eksekutif (executive ombudsman) dengan menunjuk contoh beberapa negara bagian di Amerika Serikat, di mana keanggotaan ditetapkan oleh pimpinan eksekutif.

c. Tipe turunan (hybrid ombudsman) yang banyak dijumpai di negara-negara Amerika Latin, yang mengkhususkan diri di bidang hak asasi manusia.

\section{KON: Quo Vadis?}

\section{Gambaran Umum}

KON bertujuan untuk membantu. menciptakan dan atau mengembangkan kondisi yang kondusif dalam melaksanakan pemberantasan korupsi, kolusi dan nepotisme;

${ }^{27}$ Dalam melakukan perbandingan, Marten Oosting menggunakan dua indikator yakni perbedaan dari sudut tradjsi dan pengalaman berdemokrasi (established democracies dan new democracies), serta perbedaan dari sudut basis pembangunan ekonomi (developing dan developed countries). Oleh karena itu terdapatempat variasi, yaitu: (a) established democracies with developed economies, (b) new democracies with developed economies, (c) new democracies with developing economies, dan (d) traditional democracies with developing economies. Marten Oosting, "The Ombudsman: Role and Development a Comparative Perspective", Makalah disampaikan pada Seminar The Function of a Partiamentary Ombudsman in a Democratic State (Jakarta: 1999), hlm 3.

Dalam tulisannya yang lain Marten Oosting membedakan dalam tiga kategori, yakni ombudsman yang berada di established democracy countries, new democracy countries dan campuran antara keduanya (yaitu negara-negara bekas jajahan yang memelihara sistem demokrasi parlementer tapi secara ekonomi dikategorikan sebagai negara berkembang). Marten Oosting, "The Ombudsman and His Environment: A Global View" dalam Linda C. Reif (ed.), The Intemational Ombudsman Anthology (The Hague: Kluwer Law International, 1999), him 2-6. Namun pada dasarnya pembedaan yang digunakan dalam dua tulisan tersebut adalah sama. 
serta meningkatkan perlindungan hak-hak masyarakat agar memperoleh pelayanan umum, keadilan, dan kesejahteraan secara lebih baik. ${ }^{28}$ Selanjutnya, dalam Pasal 2 Keppres ditegaskan bahwa KON adalah lembaga pengawasan masyarakat yang berasaskan Pancasila dan bersifat mandiri, serta berwenang melakukan klarifikasi, monitoring atau pemeriksaan atas laporan masyarakat mengenai penyelenggaraan negara khususnya pelaksanaan oleh aparatur pemerintahan termasuk lembaga peradilan dalam memberikan pelayanan kepada masyarakat. Dalam melakukan tugas-tugasnya KON dilengkapi oleh empat Sub. Komisi, yaitu: Sub. Komisi Klarifikasi, Monitoring dan Pemeriksaan; Sub. Komisi Penyuluhan dan Pendidikan; Sub. Komisi Pencegahan; dan Sub. Komisi Khusus.

Dilihat dari inisiatif dan dasar hukum pembentukannya, KON dapat dikategorikan sebagai ombudsman eksekutif (the executive. ombudsman). Namun jika RUU tentang Ombudsman Nasional telah disahkan dan ini berarti bahwa dasar pembentukannya adalah UU, tidak dapat pula secara serta merta dikatakan bahwa KON dapat diklasifikasikan ke dalam parliamentary ombudsman. Ombudsman Federal Australia, misalnya, meskipun dibentuk berdasarkan UU tidak dapat secara murni dikatakan sebagai parliamentary ombudsman, karena sumber pembiayaan tidak berasal dari Parlemen Federal, melainkan dari eksekutif. ${ }^{29}$

Mengenai jumlah pengaduan, selama periode Januari-Mei 2002, berdasarkan paparan yang disampaikan oleh Antonius Sujata dalam Rapat Dengar Pendapat Umum dengan Komisi II DPR, KON menerima 127 pengaduan dari kalangan masyarakat berasal dari perorangan $(74 \%)$, kuasa hukum $(14 \%)$, badan hukum (2\%), dan organisasi/kelompok masyarakat (10\%)..$^{30}$ Dari jumlah laporan tersebut KON telah menindaklanjuti 97 laporan dengan meminta klarifikasi dan memberikan rekomendași kepada instansi terkait, 9 laporan dikembalikan karena berada di luar kewenangan KON, dan 13 laporan dinilai masih perlu dilengkapi dengan data pendukung. ${ }^{31}$

Instansi atau lembaga pemerintah yang diadukan mencakup lembaga peradilan (40\%), kepolisian $(20 \%)$, pemda (15\%), BPN $(8 \%)$, kejaksaan (6\%), dan $8 \%$ lainnya mengeluhkan pelayanan instansi pemerintah, badan usaha, BUMN, dan lain-lain. ${ }^{32}$ Keluhan terhadap lembaga peradilan meliputi pengadilan negeri (56\%), Mahkamah Agung (24\%), pengadilan tinggi $(16 \%)$, pengadilan agama $(2 \%)$, dan Pengadilan Tata Usaha Negara/Pengadilan Tinggi Tata Usaha Negara (2\%). ${ }^{33}$

Dilhat dari substansinya, keluhan terbanyak terkait dengan penundaan dan berlarutnya pemberian pelayanan oleh pejabat publik (23\%), bertindak tidak layak $(20 \%)$, penyimpangan

${ }^{28}$ Pasal 3 Keppres.......

${ }^{29}$ Ron McLeod, "The Role of Ombudsman". Presentasi pada Program JD. (Melbourne:The University of Melbourne Law School, 2002).

${ }^{30}$ "Peradilan Paling Banyak Dikeluhkan", Harian Media Indonesia, 14 Juni 2002. http://www.mediaindo.co.id

${ }^{31} \mathrm{lbid}$.

${ }^{32} \mathrm{lbid}$.

${ }^{33} \mathrm{lbid}$. 
prosedur $(18 \%)$, penyalahgunaan wewenang $(17 \%)$, melakukan KKN (11\%), melalaikan kewajiban $(5 \%)$, nyata-nyataberpihak (3\%), serta pemalsuan dan penggelapan barang bukti $(3 \%) .34$

Sedangkan pejabat publik yang paling banyak diadukan adalah mereka yang bekerja di kantor pelayanan publik di Jakarta (34 orang), Jawa Barat (22), Jawa Timur (19), Sumatra Utara (12), DI Yogyakarta (6), Sulawesi Utara (6), Bali (5), Kalimantan Tengah (5), Jawa Tengah (4), Sumatera Selatan (3), Kalimantan Barat (3), Sulawesi Selatan (3), Nusa Tenggara Timur (2), Maluku (2), Riau (1), Jambi (1), Nusa Tenggara Barat (1), dan Kalimantan Timur (1).35

Dari data di atas dapat disimpulkan bahwa berdasarkan wilayah, bahwa dari 130 jumlah aduan mengenai pelayanan pejabat publik, sekitar $65 \%$ ditujukan pada aparat publik di Pulau Jawa (85 aduan) dan sisanya 35\% di luar Jawa (45 aduan). Hasil ini tidak dapat secara otomatis menjelaskan bahwa kualitas pelayanan di luar Jawa lebih baik dibandingkan di Jawa. Beberapa faktor dapat melatarbelakangi jumlah aduan yang masuk, misalnyaakses ke KONhanyadapat dijangkau oleh kalangan tertentu, keberadaan KON belum diketahui secara luas oleh masyarakat di luar Jawa, dan lain sebagainya.

\section{Dua Tahun KON: Evaluasi Awal}

Ruzindana, seorang anggota Pariemen Uganda, menyatakan bahwa diskursus dan kontroversi ombudsman terpusat pada aspek- aspek: fungsi, kewenangan melakukan penyelidikan, yurisdiksi, independensi, akses, fleksibilitas, penerapan hasil temuan atau rekomendasi, kecepatan, serta kepribadian para anggotanya. ${ }^{36}$ Guna keperluan analisis, Penulis hanya akan menyoroti dua aspek utama yaitu luas lingkup kewenangan serta penerapan hasil temuan atau rekomendasi.

\section{a. Luas Lingkup Kewenangan}

Secara eksplisit Keppres telah mengatur kewenangan KON untuk melakukan klarifikasi, monitoring atau pemeriksaan atas laporan masyarakat mengenai penyelenggaraan negara khususnya pelaksanaan oleh aparatur pemerintahan termasuk lembaga peradilan. Di dalam Konsep RUU tentang Ombudsman Nasional disebutkan bahwa laporan masyarakat tersebut dapat berupa keluhan atau aduan mengenai keputusan, tindakan dan atau perilaku pejabat pemerintahan dan peradilan. Selengkapnya usulan ketentuan itu berbunyi: ${ }^{37}$ "Ombudsman Nasional berwenang:

a. Menerima laporan dari masyarakat yang berisi keluhan atas keputusan, tindakan dan atau perilaku pejabat penyelenggara negara dan penyelenggara peradilan yang dirasakan tidak adil, tidak patut, memperlambat, merugikan atau bertentangan dengan kewajiban hukum instansi yang bersangkutan atau tindakan maladministrasi lainnya sebagaimana dimaksud dalam undang-undang ini termasuk pelanggaran terhadap hak asasi

${ }^{34}$ Ibid.

${ }^{35} \mathrm{lbid}$.

${ }^{30}$ A. Ruzindana, "The Role of the Ombudsman in Enforcing Accountability" dalam Linda C. Reif (ed.), The International Ombudsman Yearbook Volume 3(The Hague: Kluwer Law International, 1999), hIm 182.

${ }^{3}$ Pasail 7 RUU tentang Ombudsman Nasional. 
Hi.pribadis "dani 'golongan dalam masyarakat::" i.l' "ll is "i

Dalam usulan ketentuan lainnya, yang berkenaan dengan luas lingkup kewenangan dinyatakan: ${ }^{38}$

"Kewenangan Ombudsman Nasional adalah memeriksa baik berdasarkan laporan penduduk atau warga negara maupun atas inisiatif sendiri (ex officio) terhadap:

a. Pelaksanaan tugas pelayanan para Menteri, termasuk Sekretaris Negara dan Sekretaris Kabinet, segala jenis dan tingkatan Pengadilan, Pegawai Negeri, termasuk petugas dan pejabat militer, kepolisian, dan kejaksaan serta pejabat pemerintahan lainnya; segala jenis dan tingkatan hakim serta pegawai dan pejabat administrasi segala jenis dan tingkatan peradilan; pejabat dan pegawai perusahaan negara, Universitas dan Lembaga Pendidikan Negeri, Rumah sakit dan lain-lain instansi publik..."

Dari kedua usulan ketentuan di atas dapat dilihat bahwà KON mempunyai kewenangan yang sangat luas, sehingga dapat dikatakan KON memiliki general jurisdiction Tampaknya hal ini sejalan dengan keinginan KON yang tidak mentolerir pendirian ombudsman-ombudsman lain yang mempunyai specific jurisdiction, misalnya ombudsman di bidang pendidikan, telekomunikasi, dan lain-lain. ${ }^{39}$
Hal ini dapat dilihat dalam Pasal 41 ayat (1) RUU tentang Ombudsman Nasional yang selengkapnya berbunyi:

"Ombudsman yang teiah dibentuk oleh instansi pemerintah, perusahaan, lembaga swadaya masyarakat, maupun organisasi lain atau perorangan di luar Ombudsman Nasional yang dibentuk berdasarkan Keputusan Presiden Republik Indonesia Nomor 44 tahun 2000 tentang Komisi Ombudsman Nasional atau di luar Ombudsman Daerah yang dipilih dan diangkat sesuai dengan Pasal 29 ayat (3) dan (4) Undang-Undang ini dan atau tidak ada kaitannya dengan UndangUndang ini harus dibubarkan atau diganti namanya tanpa menggunakan kata "Ombudsman". (garis bawah oleh penulis)

Kewenangan KON menjadi lebih luas lagi karena lembaga ini tidak saja menerima keluhan dalam kaitan dengan keputusan penyelenggara negara atau administrasi negara, melainkan mencakup pula keluhan dalam kaitan dengan perilaku atau sikap tindak penyelenggara negara. Hal ini mirip dengan salah satu kewenangan yang dimiliki oleh Ombudsman Papua Nugini yakni mengawasi penegakan etika kepemimpinan yang dituangkan dalam Leadership Code, yakni suatu ketentuan yang terdapat dalam Konstitusi PNG Pasal 26-31 dan UU Organik tentang Tugas dan Tanggungjawab Kepemimpinan (Organic Law on Duties and.Responsibilities of Leader-

\footnotetext{
${ }^{38}$ Pasal 8 RUU tentang Ombudsman Nasional.

${ }^{39}$ Terdapat beberapa negara yang memiliki ombudsman dengan jurisdiksi spesifik, misalnya Australia. Dengan mengambil pengalaman dari sektor publik; ombudsman di sektor swasta mulai dikenal, contohnya ombudsman perbankan, ombudsman telekomunikasi, ombudsman asuransi kesehatan swasta, serta ombudsman listrik dan energi.
} 
ship). ${ }^{40}$ Regan berpendapat bahwa melalui kewenangan ini Ombudsman PNG menjadi salah satu lembaga terpenting di negara untuk menegakkan akuntabilitas. Tidak dapat disangkal lagi bahwa pengawasan terhadap etika kepemimpinan merupakan suatu hal yang sulit dan menjadi tugas yang tidak ringan bagi ombudsman. Bahkan Ron McLeod dari Ombudsman Federal Australia menyatakan bahwa ia sangat beruntung karena Ombudsman yang dipimpinnya tidak ditugasi untuk menangani keluhan yang berkaitan dengan perilaku penyelenggara negara. ${ }^{41}$

Sebagian besar negara-negara yang memiliki ombudsman memberikan kewenangan yang terbatas kepada lembaga ini. Salah satu negara yang membatasi kewenangan ombudsman (lembaga ombudsman di Inggris dikenal dengan nama Parliamentary Commissioner for Administration) adalah Inggris di mana ombudsman dilarang menampung keluhan yang berkaitan dengan:42
(1). Hubungan luar negeri.

(2). Perkara pidana dan keamanan nasional:

(3). Pemeriksaan persidangan perkara pidana atau perdata.

(4). Pelaksanaan hak prerogatif.

(5). Transaksi perniagaan atau kontrak.

(6). Gaji, disiplin, pensiun dan segala masalah kepegawaian, baik sipil maupun militer.

(7). Pemberian hak-hak istimewa.

(8). Ombudsman di bidang kesehatan tidak berwenang meneliti mengenai pertimbangan klinis (clinical judgement).

Selain itu ada negara-negara yang melarang ombudsman untuk menyelidiki keluhan di bidang peradilan. Ombudsman Denmark, misalnya, meskipun memiliki kewenangan luas yang hampir menyerupai kewenangan Ombudsman Swedia, menyatakan tidak berwenang untuk menyelidiki keluhan yang berkaitan dengan lembaga peradilan. ${ }^{43}$ Alasannya adalah bertentangan dengan prinsip kekuasaan

${ }^{40}$ Anthony J. Regan, "Papua New Guinea" dalam Cheryl Saunders \& Graham Hassall (ed), AsiaPacific Constitutional Yearbook 1996 (Melbourne: Centre for Comparative Constitutional Studies, 1998), hlm 294. Ombudsman PNG dibentuk berdasarkan UU yang disebutkan sebagai UU Organík tentang Komisi Ombudsman (the Organic Law on the Ombudsman Commission), dan berstatus lebih tinggi dibandingkan dengan UU lainnya. Bahkan Konstitusi PNG mengatur bahwa perubahan terhadap UU Organik lebih sulit dibandingkan dengan UU biasa, dan hanya dapat dilakukan dengan persetujuan suara mayoritas mutlak anggota Parlemen. Iniadalah salah satu contoh ketentuan hukum yang mengkokohkan keberadaan dan kekuatan ombudsman di PNG sebagaimana dilansir oleh de Jonge dengan mengatakan bahwa kombinasi aturan-aturan tentang ombudsman yang terdapat di Konstitusi dan UU Organik tentang Ombudsman telah menjadikan Ombudsman PNG menjadi salah satu Ombudsman terkuat di dunia. Alice de Jonge, "The Pacific Ombudsman's Complaints Function: Comparative Perspectives on Fiji, Papua New Guinea and Vanuatu, 1999, http://rspas.anu.edu.au/melanesial dejonge. html, hlm 7.

${ }^{41}$ Ron McLeod, op.cit.,

${ }^{42}$ Frank Stacey, Ombudsman Compared (Oxford: Clarendon Press, 1978), hlm 126. Selain itu, Inggris juga mendirikan the Health Service Commissioner dan the Local Commissioner for Administration.

${ }^{43} \mathrm{Namun}$ Ombudsman memiliki kewenangan untuk menyelesaikan keluhan dalam kaitan dengan administrative tribunals. Dan selama ini kasus-kasus yang diselidiki oleh Ombudsman banyak berkaitan dengan fungsi tribunal-tribunal, dan bukan berkenaan dengan anggota-anggota tribunal. Donald C. Rowat (ed), op.cit., him 79. 
kehakiman yang merdeka (tha principtojof the independencerios theritudicians) rdan keluhan dalam kaitanr-dengan peradilan dapat disampaikan ke the Court of Complaints. ${ }^{44}$

Luasnya ruang lingkup ini membawa pengaruh baik positif maupun negatif. Di satu sisi, luasnya kewenangan membuat masyarakat dapat menyampaikan keluhan secara lebih leluasa. Artinya kehadiran KON sebagai lembaga yang memperluas pilihan masyarakat semakin terasa. Namun di sisi lain, akan sangat membahayakan. Pertama, akan terjadi tumpang tindih dengan fungsi-fungsi lembaga lain, dan kedua, tidak mungkin dikerjakan karena akan teralu banyak. ${ }^{45}$ Atau dengan kata lain akan terjadi banjir (flooding) keluhan.

Terhadap alasan yang pertama, misalnya, di Indonesia telah didirikan Komisi Nasional Hak Asasi Manusia (Komnas HAM) berdasarkan Keppres No. 50 Tahun 1993 yang kemudian keberadaannya dikukuhkan melalui UU No. 39 Tahun 1999 tentang HAM. Apabila KON tetap bersikukuh untuk melaksanakan kewenangannya di bidang HAM, maka tak pelak lagi akan timbul friksi antara kedua lembaga ini. Dalam kaitan dengan lembaga peradilan, Pasal 24B Perubahan Ketiga UUD 1945 telah melahirkan suatu Komisi yang dinamakan dengan Komisi Yudisial. Dalam ayat (1) disebutkan bahwa Komisi Yudisial bersifat mandiri yang berwenang mengusulkan pengangkatan hakim agung dan mempunyai wewenang lain dalam rangka menjaga dan menegakkan kehormatan, keluhuran martabat, serta perilaku hakim. Apabila Komisi ini telah berjalan, bukan tidak mungkin akan terjadi tumpang tindih kewenangan dengan KON, karena Komisi ini dapat memeriksa keluhan bukan saja berkaitan dengan administrasi peradilan (yang selama ini dipertahankan oleh KON sebagai dasar pembenar untuk melakukan supervisi terhadap peradilan), melainkan juga perilaku hakim-hakim. Tampaknya, Komisi Yudisial ini mempunyai kemiripan dengan Court Complaints yang dipunyai oleh Denmark. Dalam kaitan dengan kasus korupsi, tampaknya KON juga harus berhati-hati apabila menentukan titik berat penanganan keluhan dalam bidang ini karena akan digarap oleh Komisi Anti Korupsi.

Dalam kaitan dengan alasan kedua, sudah menjadi hal yang umum bahwa di banyaknegara, terutama di negara-negara berkembang, sumber daya yang tersedia kurang memadai. Hal serupa terjadi pula di Indonesia. Apabila KON memaksanakan diri untuk memproses keluhankeluhan akibat luasnya kewenangan yang dimiliki, maka dikhawatirkan hasil (outcome) yang dikeluarkan menjadi tidak memuaskan. Atau secara ekstrim, banyak keluhan yang tidak tertangani. Akibatnya, kredibilitas KON akan menjadi turun karena ketidakmampuannya menangani semua keluhan yang masuk yang pada gilirannya akan menurunkan kepercayaan masyarakat terhadap lembaga ini.

Selain itu perlu pula dikritisi apakah dengan banyaknya lembaga serta pejabat publik yang menjadi sasaran pengawasan, KON mampu melaksanakan tugas-tugas lain, misainya sosialisasi, kerjasama, dan lain-lain, yang dalam RUU tentang Ombudsman Nasional dikatakan sebagai fungsi pengkajian dan penelitian:

\footnotetext{
4/bid.

${ }^{45}$ Bagir Manan, op.cit., hlm 5.
} 
Oleh karena itu menjadi sangat krusial bầgi KON untuk membatasi kewenangan yang dimilikinyà yang disesuaikan dengan perkembangan ketatanegaraan yang terjadi di Indonésia dan realitias kemampuan yang dimiliki. Dalam kaitan ini, penulis berpendapat bahwa sebaiknya KON hanya memusatkan perhatian pada keluhan yang berkaitan dengana administrasi negara, dan melepaskan diri dari urusan-urusan peradilan dan HAM. Hal ini dilandasi pada dua alasan yakni: pertama, luasnya pengertian administrasi negara sebagaimana dipaparkan di bawah ini, yang kemudian dapat menunjukkan luasnya bidang garapan KON. Kedua, bahwa saat ini beium terdapat satu badan independen yang kuat dan netral untuk menangani keluhan di bidang administrasi negara. ${ }^{46}$

Apakah yang dimaksudkan dengan administrasi negara? Bagir Manan ${ }^{47}$ menyatakan bahwa penyelenggaraan pemerintahan yang dilaksanakan oleh Presiden sebagai kekuasaan eksekutif dapat dibedakan antara kekuasaan penyelenggaraan pemerintahan yang bersifat umum dan khusus. Yang bersifat umum adalah kekuasaan menyelenggarakan administrasi negara, yang tugas dan wewenangnya dapat dikelompokkan ke dalam beberapa golongan, yaitu:

(1), Tugas dan wewenang administrasi di. bidang keamanan dan ketertiban negara;

(2). Tugas dan wewenang menyelenggarakan tata usaha. pemerintahan mulai dari surat menyurat sampai kepada dokumentasi, dan lain-lain;

(3) Tugas dan wewenang administrasi negara di bidang pelayanan ùmum; dan

(4) Tugas, dan wewenang administrasi negara. di bidang penyelenggaraan kesejahteraan umum.

- Meskipun Bagir Manan juga menegaskan bahwa fúngsi pemeliharaan keamanan dan ketertiban dapat juga dilaksanakan oleh lembaga peradilan, namún administrasi negara tétap memegang peranan utama dalam bidang ini. Sedangkan yăng bersifat khusus adalah penyelenggaraan tugas dan wewenang pemerintahan yang secara konstitusional ada pada Presiden yang memiliki sifat prerogatif, misalnya pengangkatan menteri, dan lain-lain. Apabila KON hendak memusatkan bidang tugasnya pada penyelenggaraan negara, dalam hal ini adalah eksekutif, maka hanya penyelenggaraan yang bersifat umumlah yang dapat diawasi oleh KON. Sedangkan yang' bersifat khusus tidak dapat dijadikan objek pengawasan KON.

Melihat pada luasnya cakupan administrasi negara, yang meliputi tingkat nasional, provinsi, kota, dan kabupaten maka menjadi relevan untuk dilakukan pengkajian guna meneliti kemungkinan perlunya pendirian ombudsman daerah. 'Jika suatu ketika daerah membentuk ombudsman maka perlu diperhatikan beberapa hal, antara lain:

(1) Urgensi pendirian. Penulis berpendapat bahwa tiap daerah tidak dapat dipaksa untuk membentuk ombudsman, melainkan harus berdasarkan kepentingan daerah yang bersangkutan.

\footnotetext{
${ }^{48}$ Lihat paparan pada Bagian B dan C.

${ }^{47}$ Bagir Manan, op.cit., hlm 122-128.
} 
(2) Syarat pembentukannya tetap harus memperthatikân standar-standar yang berläkü secara universal, misainya independen, imparsial dan lain-lain.

(3) Kewenangannya hanya mencakup urusan rumah tangga daerah serta memperhatikan karakteristik daerah yang bersangkutan. Bukan tidakmungkin ada daerah yang mengkhususkan objek pengawasan pada bidang tertentu, misalnya lingkungan hidup.

\section{b. Penerapan Hasil Temuan atau Rekomendasi}

Berdasarkan Buku Laporan Tahunan $2000^{48}$ yang diterbitkan KON dapat diketahui bahwa dari periode Maret - Desember 2000, surat pengaduan yang masuk berjumlah 1.717 buah. Sejumlah 1.425 kasus telah diproses, sedangkan respons dari rekomendasi masih terbilang rendah yakni hanya 494 respons atau sekitar 35 persen dari seluruh jumlah pengaduan. Padahal ditinjau dari ukuran keberhasilan suatu lembaga dikatakan beriasil apabila keputusannya dapat dipatuhi atau dilaksanakan.

Salah satu ciri khas yang membedakan ombudsman dengan peradilan terletak pada sifat rekomendasinya yang tidak mengikat secara hukum (non-legally binding). Sebagai upaya untuk memperkuat rekomendasi, dalam RUU tentang Ombudsman Nasional dimasukkan ketentuan sanksi administrasi bagi para penyelenggara negara yang tidak mematuhi rekomendasi sebagaimana tercantum dalam
Pasal 42, yang memberikan sanksi,administratif berupa pemecatan dan atau sanksi administratif lain dan atau denda administratif setinggi-tingginya Rp 10 milliar.

Terdapat beberapa pertanyaan terhadap Rancangan tersebut. Pertama, apakah yang dimaksudkan sebagai sanksi administratif lain? Apakah termasuk jenis sanksi administrasi yang dikenal, misalnya uang paksa (dwangsom), paksaan pemerintah, dan lain-lain. Kedua, bagaimana KON dapat menegakkannya apabila RUUinidisahkan. Apakah KON sendiriyang akan melakukannya ataukah akan melalui pengadilan dan pengadilan manakah yang berwenang melakukannya? ApabilaKON yang menegakkan, pertanyaan selanjutnya adalah apa perbedaan ombudsman dengan pengadilan? Apabila penegakkannya dilakukan oleh PTUN, apakah keputusan.atau rekomendasi KON dapat dikategorikan sebagai putusan administrasi negara?

Ketika ombudsman hendak dibentuk di Hong Kong, sekitar tahun 1988, terdapat usulan agar ombudsman mempunyai wewenang untuk penegakan, yakni wewenang untuk melakukan "kecaman" terhadap pemerintah (to censure the govemment), mengesampingkan kebijakan yang tidak populer (to reverse unpopular policies), menindak pejabat pemerintah dan memerintahkan pemberian uang ganti rugi bagi korban (to prosecute govemment officials and pay compensation to aggrieved individuals). Ușulan-usulan tersebut ditolak dalam pembahasan RUU di Legislative Council. ${ }^{49}$

${ }^{48}$ Komisi Ombudsman Nasional, Laporan Tahunan 2000 (Jakarta: Komisi Ombudsman Nasional, 2000), hlm 14-16.

${ }^{49}$ M.J.A. Cooray, "Hong Kong's Ombudsman: The First Decade" dalam Linda C. Reif (ed), The Intemational Ombudsman, Yearbook Vol. 3 (The Hague: Kluwer Law international, 1999), hlm 85. 
Agar rekomendasi KON dapat ditaati, Bagir Manan $^{50}$ berpendapat diperlukan dukungan teknis dan non-teknis. Dukungan non-teknis termasuk lingkungan pemerintahan yang baik (good govemance) yaitu pemerintahan yang bersih, terbuka, terkontrol dan bertanggung jawab. Pemerintahan semacam itu hanya mungkin terbentuk dalam sistem politik terbuka yakni demokrasi. Sikap masyarakat yang demokratis, berani menyampaikan keluhan, dan tidak berkompromi pada segala bentuk penyelewengan merupakan bentuk-bentuk dukungan sosial yang sangat berarti bagi KON.

Secara teknis, kekuatan rekomendasi KON akan ditopang oleh:

(1) Sistem pendekatan dalam menemukan masalah. Maksudnya, selain menggunakan pendekatan formal (surat-menyurat, investigasi, meminta penjelasan, dan lainlain), KON dapat pula mengembangkan pendekatan informal melalui cara-cara tertentu yang mampu mendorong pembuat keputusan melakukan perbaikan sendiri.

(2) Sistem pelaporan kepada DPR. Dengan laporan ini DPR akan mengevalusi, menilai dan membuat kebijakan yang relevan dengan laporan KON.

(3) Sistem publikasi secara periodik.

(4) Adanya kewenangan untuk melaporkan kepada pihak yang berwenang agar diadakan penyelidikan, penyidikan sampai pada penindakan secara hukum suatu badan atau pejabat yang tidak mengindahkan rekomendasinya.

\section{KON Masa Depan: Proposal \\ Pembaharuan}

Tak dapat dipungkiri bahwa pendirian KON telah memiunculkan angin segar bagi perbaikan proses penyelenggaraan negara, baik di tingkat pusat maupun daerah. Namun di sisi lain harus diakui bahwa KON belum berfungsi secara maksimal sebagaimana diharapkan oleh masyarakat.

Untuk menjadi suatu lembaga yang efektif, terdapat beberapa syarat yang perlu diperhatikan, yakni: ${ }^{51}$

1. Dukungan politik yang berasal dari legislatif, eksekutif, administrasi negara atau birokrasi serta peradilan.

2. Sumberdaya yang memadai, yang diwujudkan antara lain dalam bentuk anggaran yang cukup untuk menjalankan seluruh fungsi ombudsman.

3. Persepsi masyarakat, artinyá masyarakat harus menyadari dan memahami makna dan fungsi ombudsman.

4. Kompetensi fungsional. Maksudnya ombudsman harus seefektif mungkin untuk menerima, menyelidiki, dan menyelesaikan keluhan. Hal ini akan sangat tergantung pada disain atau model kelembagaan, kapasitas administrasi, profesionalisme, bebas. dari pengaruh eksekutif, prosedur atau mekanisme dalam menghadapi pemerintah, menterimenteri serta departemen-departemen. Sebagai ilustrasi, Ombudsman Georgia telah menerima 100.000 keluhan dalam

${ }^{50}$ Bagir Manan, "Fungsi Ombudsman," op. cit., hlm 3-4

. ${ }^{51}$ Nick Manning dan D.J. Galligan, "Using an Ombudsman to Oversee Public Officials", Working Paper. Prem Notes Public Sector No. 19. The World Bank. http://www.worldbank.org 
awal-awal masa pendiriannya. Akan tetapi karena ketidakmampuannya, banyak keluhan yang kemudian tidak dapat diproses.

5. Nilai pengaturan (regulatory value). Artinya, ombudsman harus seșuai dengan struktur yang ada di bidang administrasi. Regulatory value ini akan tergantung pada keseluruhan sistem pengaturan di bidang administrasi dalam suatu negara, dan bagaimana ombudsman secara tepat menempatkan diri dalam sistem tersebut. Selain itu, faktor ketahanan ombudsman dalam jangka waktu tertentu juga akan sangat mempengaruhi regulatory value ini.

Kelima syarat di atas akan digunakan oleh Penulis dalam upaya menawarkan perbaikan dan pembaharuan KON di masa-masa mendatang.

\section{Dukungan Politik}

Banyak kalangan akademisi berpendapat bahwa pendirian ombudsman yang dilakukan oleh parlemen membawa pengaruh atau akibat yang cukup signifikañ dibandingkan dengan pendirian yang dilakukan oleh pimpinan eksekutif. Atau dengan kata lain, parliamentary ombudsman dipandang memiliki keberadaan yang lebih kokoh dibandingkan dengan executive ombudsman. Pendapat ini dapat dibenarkan apabila menggunakan alasan dasar hukum pembentukan (legal basis) ombudsman. Jika menggunakan UU maka keberadaannya akan lebih aman karena ombudsman tidak dapat dibubarkan begitu saja. Sedangkan apabila dibentuk oleh keputusan pimpinan eksekutif maka ombudsman dapat dibubarkan sewaktuwaktu karena proses perubahan atau pencabutannya tidak memerlukan persetujuan parlemen atau legislatif.

Namun terlepas dari kontroversi dasar pembentukan, dukungan politik dari legislatif, eksekutif (dalam arti Presiden bersama para menteri), birokrasi serta lembaga peradilan merupakan faktor yang tidak dapat diabaikan untuk menciptakan suatu ombudsman yang efektif. Dukungan-dukungan itu dapat diwujudkan dalam berbagai cara. Dukungan dari legislatif dapat dilakukan manakala lembaga ini berperan dalam proses pemilihan para anggota ombudsman. Para anggota yang dipilih dapat dipandang telah mendapatkan dukungan dari partai-partai politik yang ada di parlemen. Selain itu, dukungan juga dapat diperlihatkan manakala partemen menindaklanjuti laporan yang disampaikan oleh ombudsman, terutama apabila berkenaan dengan keengganan instansi yang berada dalam jajaran eksekutfifuntuk melaksanakan rekomendasi ombudsman.

Dalam kaitan dengan Indonesia, dalam RUU tentang Ombudsman Nasional diatur bahwa Ketua Ombudsman akan dipilih oleh DPR, sedangkan Deputi Ombudsman diangkat oleh Kepala Negara atas usul Ketua Ombudsman dengan sepengetahuan DPR. ${ }^{52}$ Wakil Ketua Ombudsman ditunjuk oleh Ketua Ombudsman dari antara para Deputi Ombudsman.

\footnotetext{
${ }^{52}$ Pasal 31 ayat (1) dan (2) RUU tentang Ombudsman Nasional. Penulis berpendapat adalah tidak relevan lagi mengadakan pembedaan antara kepala negara dengan kepala pemerintahan dalam sistem pemerintahan presidensil. Karena dalam sistem ini kedua sebutan itu disandang oleh orang yang sama, yakni yang disebuit sebagai presiden.
} 
Tidak ada penegasan lebih lanjut apakah yang dimaksud dengan "sepengetahuan" di sini. Anehnya, apabila dalam proses pengisian jabatan Wakil Ketua dan Deputi Ombudsman Dewan tidak terlibat secara penuh, namun dalam proses penghentian kedua jabatan tersebut DPR mempunyai peran yang cukup signifikan, yaitu harus memberikan persetujuannya. Apakah dengan menyandingkan kedua ketentuan ini kemudian dapat ditafsirkan bahwa "sepengetahuan" berarti "persetujuan"? Namun apabila menggunakan penafsiran gramatikal, kata "sepengetahuan" mempunyai art yang berbeda dengan "persetujuan". Apabila menggunakan penafsiran sistematis, seharusnya pengisian jabatan Wakil Ketua Ombudsman harus mendapatkan persetujuan DPR. Karena apabila Ketua Ombudsman berhenti, maka Wakil Ketua akan menjalankan tugas dan kewenangan Ketua sampai dengan terpilihnya Ketua Ombudsman yang baru. Meskipun tidak dikatakan bahwa Wakil Ketua secara otomatis menggantikan Ketua, namunia tetap harus mendapatkandukungan dari Dewan karena berkaitan dengan keberadaan lembaga yang untuk sementara dipimpinnya.

Kritik lain terhadap ketentuan di atas yakni mengapa tidak diadakan simplifikasi ketentuan yang berkenaan dengan klausul keadaan berhalangan. Dalam pandangan penulis, demi tercapainya efektivitas dan efisiensi kelembagaan sudah selayaknya jika jabatan Ketua Ombudsman lowong maka secara otomatis diganti oleh Wakil Ketua, sehingga DPR tidak lagi diharuskan memilih Ketua Ombudsman yang baru. Menjadi persoalan apabila kemudian Dewan lambat atau bahkan tidak melakukan pemilihan yang dimaksud. Kenyataan sudah menunjukkan bahwa makin banyaknya jabatan yang harus mendapatkan persetujuan atau pertimbangan dari Dewan, antara lain menimbulkan kesulitan dan kelambatan dalam hal-hal tertentu. ${ }^{53}$

Terlepas dari kontroversi di atas, salah satu kekuatan ombudsman berdasarkan RUU tersebut adalah adanya ketentuan yang mewajibkan lembaga ini untuk menyerahkan laporan insidensil dan tahunan kepada DPR dan laporan itu harus dibahas secara seksama oleh Dewan sebagaimana tertera dalam Rancangan Pasal 37 ayat (4) dan (5) jo Pasal 39. Setelah diserahkan maka laporan itu dapat disebarluaskan melalui media massa. Salah satu isi laporan tahunan adalah tentang pejabat instansi yang tidak bersedia memenuhi permintaan danlatau melaksanakan rekomendasi Ombudsman Nasional. ${ }^{54}$ DPR

${ }^{53}$ Salah satu contoh dari kesulitan yang ditimbulkan adalah pelaksanaan ketentuan Pasal 13 Perubahan Pertama UUD 1945 yang mengharuskan Presiden memperhatikan pertimbangan DPR dalam pengangkatan duta besar. Saat ini "pertimbangan" ditafsirkan sebagai semacam "fft dan proper tesf" sebagaimana dilakukan terhadap pemilihan hakim-hakim agung. Beberapa ahli Hukum Tata Negara menyatakan bahwa ketentuan ini tidak sejalan dengan doktrin yarig dikenal dalam Hukum Tata Negara yang menyatakan bahwa hubungan luar negeri merupakan exclusive powerdari eksekutif. Oleh karena itu, campur tangan DPR menjadi tidak relevan dalam hal pengangkatan duta besar.

${ }^{54}$ Selain hal di atas, laporan tahunan berisi: a. Jumlah dan macam keluhan atau laporan yang diterima dan ditangani selama satu tahun; $b$. Pejabat atau instansi yang tidak bersedia atau lalai melakukan pemeriksaan terhadap pejabat yang mendapat keluhan dan tidak mengambil tindakan administrasi atau tindakan hukum terhadap pejabat yang terbukti bersalah; $c$. Pembelaan atau sanggahan dari atasan pejabat yang mendapat keluhan atau dari pejabat yang mendapat keluhan itu sendiri; $d$. Jumlah dan macam keluhan atau laporan yang 


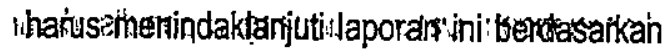

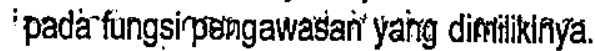

Namun "vsesungguhriya' rombudsman mempunyai senjata lain yang cukup ampuh untuk memperkuat keberadaannya, yakni dengan adanya kewenangan untuk mempublikasikan melalui media massa (cetak dan elektronik) dan mendiskusikan salah satu isu penting berkenaan dengan aduan yang sedang ditangani. Meskipun menurut Kimweri pemberitaan melalui media massa ini lebih banyak dipengaruhi oleh budaya, namun setidak-tidaknya di Tazmania menunjukkan bahwa penyebarluasan informasi tentang maladministrasi melalui media massa telah memberikan hasil yang baik bagi executive ombudsman di Tazmania.55 Paling tidak terdapat tiga manfaat mempergunakan cara ini, yaitu: pertama, masyarakat akan sadar terhadap keberadaan lembaga ini dan mendorong pihak yang dirugikan oleh aparat pemerintah untuk melaporkan. Kedua, cara ini merupakan peringatan yang bersifat tetap terhadap penyelenggara negara bahwa ombudsman melakukan pengawasan dan hasil kerja mereka akan secara teratur dipublikasikan kepada masyarakat luas. Ketiga, aparat penyelenggara negara akan bertindak lebih berhati-hati karena sesungguhnya tidak ada seorangpun yang menginginkan kesalahannya diumumkan kepada publik. ${ }^{56}$
Sementara itu dalam kaitan dengan dukungan dari eksekutif, Antonius Sujata justru menyatakan bahwa eksekutif tampaknya kurang memberikan dukungannya. Hal ini terlihat nyata dengan belum diresponsnya RUU tentang Ombudsman Nasional oleh pihak eksekutif. ${ }^{57}$ Ketidakpedulian itu kelihatannya dilandasi oleh kekurangpahaman Presiden Megawati tentang fungsi ombudsman dalam upaya pemberantasan KKN. Sikap ini jelas berbeda dengan sikap Pemerintahan Wahid yang memberikan kesempatan seluas-luasnya kepada masyarakat untuk melakukan fungsi kontrol terhadap aparatur pemerintahan. Dalan pandangan Sujata, Pemerintahan Megawati beranggapan bahwa pengawasan terhadap administrasi negara sudah cukup dilaksanakan oleh Pengadilan Tata Usaha Negara (PTUN). ${ }^{58}$

Resistensi semacam ini tentunya akan sangat membahayakan bagi upaya tercapainya tujuan pembentukan KON. Bukan saja dalam kaitan dengan anggaran, namun yang lebih prinsipil adalah pada kemauan dari eksekutif untuk melaksanakan rekomendasi KON. Jika pimpinan eksekutif memandang bahwa KON merupakan suatu "ancaman" bagi jajarannya, maka kemungkinan besar sangat sedikit rekomendasi yang dilaksanakan. Namun tampaknya ketidakpedulian itu tidak akan

ditolak untuk diperiksa karena tidak termasuk wewenang Ombudsman Nasional atau telah terjadi paling lama dua tahun sebelum keluhan atau laporan disampaikan; e. Kegiatan-kegiatan yang sudah dijalankan, program kerja yang sudah maupun yang belum terlaksana dan hal-hal lain yang dianggap perlu.

${ }^{55}$ Mjemmas G.J. Kimwer, "The Effectiveness of an Executive Ombudsman" dalam Linda C. Reif (ed), The International Ombudsman Anthology (The Hague: Kluwer Law International, 1999), hlm 403.

${ }^{58}$ Ibid., hlm 404.

57 "Pemerintahan Megawati Masih Cuek Terhadap Keberadaan KON". 14 Februari 2002. http:/l unw.hukumonline.com

${ }^{56} /$ bid 
sampai pada sikap membubarkan KON karena dapat dipandang sebagai suatu tindakan yang sangat tidak popular dan kontraproduktif.

Salah satu cara untuk menanggulangi hal itu antara lain dengan mengembangkan kerjasama dengan berbagai pihak, 'terutama legislatif. DPR diharapkan mampu "menekan" eksekutif melalui berbagai wewenang yang dimilikinya, yang diwujudkan dalam hak-hak yang dimiliki oleh Dewan. Selain itu KON juga dapat mengembangkan kerjasama dengan media massa untuk dapat membentuk opini publik.

\section{Sumberdaya yang Memadai}

Setiap lembaga pasti membutụhkan dana untuk membiayai seluruh kegiatannya. Kekuatan pihak yang mempunyai "dompet" inilah yang diperkirạkan mampu mempengaruhi suatu institusi tertentu.

Berdasarkan Pasal 17 Keppres, pembiayaan KON sepenuhnya berasal dari eksekutif melalui anggaran Sekretariat Negara. Sedangkan dalam RUU dikatakan bahwa anggaran dibebankan kepadaAPBN. Rancangan ini dapat menyiratkan tiga hal, yakni anggaran berasal dari APBN tetapi dimasukkan ke dalam bidang eksekutif sebagaimana yang berlaku sekarang, ke dalam bidang legislatif, atau malah Ombudsman diberikan wewenang untuk mengelola anggaran sendiri.

Sebagai perbandingan ${ }^{59}$, anggaran $0 \mathrm{~m}-$ budsman Norwegia direncanakan oleh $\mathrm{Om}$ budsman dan diajukan ke Storting Presidium suatu lembaga yang berwenang untuk mengelola administrasi the Storting ${ }^{60}$ - yang terdiri dari perwakilan partai-partai politik terbesar di the Storting. Setelah melalui pembahasan yang seksama (dapat melibatkan Ombudsman apabila dipandang perlu), maka anggaran itu akàn dijadikan satu dalam anggaran the Storting. Secara konstitusional dan formal, anggaran untuk the Storting, Ombudsman dan Badan Audit akan dimasukkan dalam proposal pengajuan anggaran Pemerintah yang disampaikan kepada the Storting. Meskipun masuk dalam bagian anggaran Pemerintah, namun dari mekanisme penyiapannya tidak terlihat campur tangan Pemerintah. Akan tetapi pertanyaan tetap

${ }^{59}$ Arne Fliflet, "The Ombudsman's Budget, Accounts and Audit - Their Influence on the Ombudsman's Ability to Fulfil His Responsibilities" dalam Linda C. Reif (ed), The Intemational Ombudsman Yearbook Vo!. 1 (The Hague: Kluwer Law Intemational, 1997), him 49-54.

${ }^{\circ}$ The Storting adalah semacam National Assembly yang beranggotakan 150 anggota, yang terdiri atas dua kamar yakni the Lagting (38 anggota) dan the Odelsting (112 anggota). UU yang akan mempengaruhi hak dan kwajiban warganegara harus berasal dari the Odelsting, meskipun dapat disampaikan oleh Kabinet sebagai bentuk RUU yang disponsori oleh Pemerintah (Government-sponsored bill). Namun RUU semacam itu harus dibahas dan mendapat persetujuan dari masing-masing kamar. The Storting akan bertindak sebagai majelis 1 kamar apabila membahas masalah-masalah yang berkenaan dengan perubahan konstitusi, ratifikasi perjanjian internasional, penetapan pajak-pajak baru, serta pemberian dana-dana bantuan. Sedangkan dalam perkara impeachment anggota the Storting, Mahmakah Agung atau Kabinet, the Odelsting bertindak sebagai penuntut sedangkan the Lagting bersama-sama dengan Mahkamah Agung bertindak sebagai lembaga pemutus. Walter Gellhom, Ombudsmen and Others: Citizens' Protector in Nine Countries (Cambridge: Harvard University Press, 1967), him 160. 


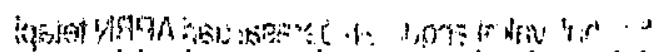
muncul-berkenąan. dengan mekanișme ini, yaitu apakah.dan bagaimana.Pemerintah dapat memainkan peranan politiknya melalui perwakilan-perwakilan partai politik (yang notabene adalah partai yang berkuasa) dalam the Storting Presidium.

Pembahasan anggaran ombudsman selanjutnya ditangani oleh salah satu komite di the Storting yakni the Standing Committee on Scrutiny and Constitutional Affairs. Meskipun ada kekhawatiran Pemerintah dapat ikut "bermain" mengendalikan anggaran ombudsman, namun selama ini tidak pernah ada pengalaman dari pihak-pihak yang berwenang untuk membatasi anggaran Ombudsman. Malah sebaliknya, the Storting seringkali meminta Ombudsman untuk memberitahukan kepadanya apabila membutuhkan tambahan dana. Oleh karena itu isue yang ada di Norwegia tidak berada pada level keuangan dan anggaran belanja, melainkan pada tataran administrasi dan pelaksanaan pemerintahan. Lembagalembaga administrasi yang menjadi objek Ombudsman dapat mengalami perubahan, dan perubahan ini tentu akan mempengaruhi struktur dan tata kerja Ombudsman.

Rekening Ombudsman disimpan oleh Kantor Akunting Pemerintah yang dikelola dan berada di bawah pengawasan Pemerintah. Anggaran ini diaudit oleh the Office of Auditor General - yang merupakan salah satu lembaga pengawasan yang dimiliki oleh the Storting: Karena berada di Kantor Akunting Pemerintah, masyarakat melalui UU Kebebasan Memperoleh Informasi dapat memantau penggunaan dana ombudsman. Meskipun terasa agak janggal, kenyataan menunjukkan bahwa mekanisme ini telah meningkatkan kepercayaan masyarakat terhadap Ombudsman.
Pelajaran apakah yang dapat ditarik dari pengalaman Norwegia di atas? Di indonesia, meskipun persetujuan anggaran diperoleh melalui DPR, namun dalam hal penyiapan anggaran pihak eksekutif, terutama Direktorat Jenderal Anggaran, memegang peran் yang sangat dominan untuk menentukan porsi bagi masing-masing institusi atau lembaga. Menjadi penting untuk mencari jalan keluar mengurangi dominasi yang sangat merugikan institusi yang tidak berada di bawah lingkungan kekuasaan eksekutif, misainya Komnas HAM.dan KON. Salah satunya adalah dengan memasukkan anggaran ombudsman sebagai bagian dari anggaran Dewan, yang kesemuanya diatur dalam klausul tata cara penyiapan anggaran ombudsman dalam RUU mendatang.

\section{Persepsi Masyarakat}

Masyarakat mempunyai peran yang tidak dapat diabaikan untuk membesarkan KON. Ombudsman merupakan istilah yang asing bagi telinga masyarakat Indonesia, oleh karena itu KON harus bekerja keras untuk mensosialisasikan fungsi, tugas dan wewenangnya kepada masyarakat dengan menggunakan bahasa yang mudah dimengerti oleh masyarakat. Dalam prakteknya KON dapat mengadakan kerjasama dengan LSM, Universitas maupun lembaga-lembaga terkait lainnya untuk menyelenggarakan workshop, diskusi dan seminar.

- Selain itu, persepsi masyarakat akan terbangun dengan baik apabila KON dapat menunjukkan hasil kerjanya kepada masyarakat, yang antara lain dapat dilakukan melalui publikasi yang secara teratur dapat diakses dengan mudah oleh berbagai kalangan. 


\section{Kompetensi fungsional}

Sebagaimana disebutkan di atas bahwa kompetensi fungsional akan bergantung pada beberapa hal, antara lain disain awal lembaga, kemampuan administrasi, profesionalisme, bebas dari pengaruh eksekutif, serta prosedur dalam berhadapan dengan pemerintah, menteri-menteri dan departemen-departemen.

Umumnya pembentukan atau pendirian suatu institusi baru didahului dengan serangkaian penelitian yang memuat paparan secara komprehensif, yang antara lain mencakup isue mengenai urgensi pendirian, pengalaman dari negara-negara lain (baik keberhasilan maupun kegagalan), dan lain-lain. Belanda, misalnya, melakukan penelitian secara seksama selama kurang lebih 10 tahun sebelum memutuskan mendirikan ombudsman. Hal serupa dilakukan oleh Australia, meskipun dalam kurun waktu yang lebih singkat.

Salah satu tulisan yang dengan baik menguraikan tentang pendirian ombudsman disajikan oleh Sir John Robertson, yang berpengalaman sebagai konsultan Pemeritah Malta pada saat negara itu hendak mendirikan ombudsman..$^{61}$ Dalam tulisannya, Robertson menjelaskan tahapan-tahapan yang umum dilaksanakan adalah:

\section{a. Manajemen Proyek}

Pada tahap ini Pemerintah sudah harus menentukan bagaimana proyek akan dikelola, dan untuk menjamin kelangsungan selama keseluruhan proses, maka sangat disarankan untuk memilih full-time project officer. Pimpinan proyek sewajamya dijabat oleh warga negara dari negara yang bersangkutan yang mengenal secara utuh mekanisme penyelenggaraan pemerintahan. Dia tidak harus orang yang mengetahui secara.mendalam tentang ombudsman, karena pengetahuan itu dapat dipelajari dan diperoleh lewat berbagai macam cara. Yang paling penting ialah orang yang bersangkutan berada dalam posisi yang memungkinkannya memperoleh seluruh informasi yang dibutuhkan, dapat mendesain strategi pelaksanaan dan melaksanakannya.

Orang-orang dapat mengatakan bahwa ombudsman merupakan konsep yang bersifat internasional, dan untuk menempatkannya secara tepat dalam sistem penyelenggaraan pemerintahan hanyalah dapat dilakukan oleh mereka yang mempunyai pengetahuan tentang sistem itu dengan baik. Untuk itu dibutuhkan keahlian di bidang-bidang yang bersangkutan dengan tujuan pembentukan ombudsman, misalnya Hukum Administrasi Negara, Hukum Tata Negara, Kebijakan Publik, Administrasi Negara, dan lain-lain.

\section{b. Proses otorisasi}

Proses ini terbagi dalam lima elemen yang meliputi:

(1) Proses penyiapan dasar hukum (dalam konstitusi atau UỤ).

(2) Proses konsultasi.

(3) Pengesahan peraturan yang menjadi dasar hukum pembentukan.

(4) Penunjukkan ombudsman

(5) Penyebarluasan informasi pembentukan ombudsman.

Beberapa hal yang krusial untuk didiskusikan

${ }^{61}$ Sir John Robertson, "Setting Up An Ombudsman Office" dalam Linda C. Reif (ed), The Intemational Ombudsman Yearbook Vol. 11997 (The Hague: Kluwer Law International, 1997), hlm 17-36 
di tahap ini, antara lain kedudukan ombudsman dalam sistem ketatanegaraan, fungsi, tugas, wewenang, kompetensi, tata cara penyampaian aduan, penyelidikan, rekomendasi, hubungan dengan lembaga-lembaga negara lainnya, dan lain-lain. Hal-hal di atas perlu mendapat perhatian penuh karena akan berkaitan dengan desain kelembagaan.

\section{c. Pelaksanaan}

Adakalanya terjadi, legislatif telah menyetujui undang-undang pembentukan ombudsman namun implementasinya membutuhkan waktu tertentu. Sebaiknya hal ini tidak terjadi. Yang ideal adalah pada saat legislatif sedang membahas dasar hukum pembentukan, pimpinan proyek secara simultan mempersiapkan segala hal yang berkaitan dengan ombudsman. Sehingga apabila undang-undang disahkan maka ombudsman dapat langsung berfungsi.

Dalam tahap ini perlu dibuat rencana detail pelaksanaan yang mencakup:

(1) Lokasi kantor, yang diusahakan dapat secara mudah dijangkau oleh masyarakat dengan angkutan umum.

(2) Pengisian pegawai dan pelatihan

(3) Pembenahan administrasi perkantoran, misainya sistem penyimpanan data; sistem komputerisasi, surat-menyurat, dan lain-lain.

(4) Sistem manajemen perkara, apakah berdasarkan sistem manual, kombinasi manual dan komputer, ataukah sepenuhnya komputerisasi.

(5) Pendidikan, yang mencakup pendidikan terhadap masyarakat, media massa, serta pendidikan agar lembaga-lembaga yang masuk dalam pengawasan ombudsman mengerti akibat-akibat pembentukan ombudsman.

Dalam konteks Indonesia, Presiden Wahid melalui Keppres No. 155. Tahun 1999 telah membentuk Tim Pengkajian .Pembentukan Lembaga Ombudsman. Namun sayangnya masyarakat tidak pernah memperoleh informasi secara jelas dan komprehensif perihal hasil kerja Tim ini. Padahal melihat tahapan di atas, Tim ini mempunyai peran yang sangat signifikan untuk menentukan ombudsman seperti apakah yang akan dimiliki oleh Indonesia. Atau dengan kata lain grand design atau blue print ombudsman Indonesia akan ditentukan oleh hasil masukan dari Tim ini.

Akibatnya, pada saatKON dibentuk, Keppres tidak cukup, kalaupun tidak dapat dikatakan sama sekali tidak, mengatur hal-hal penting berkaitan dengan masa depan KON. Tampaknya Pemerintah saat itu mengambil sikap untuk lebih mengedepankan pembentukan lembaganya, dan membiarkan mengisi bagianbagian lembaga itu di kemudian hari. Inilah yang kemudian menimbulkan kerumitan yang mungkin dihadapi oleh KON saat ini.

Apabila suatu RUU hendak diajukan umumnya didahului oleh penulisan Naskah Akademik dari RUU dimaksud. Naskah Akademik inilah yang akan memberikan gambaran bahwa suatu RUU memang perlu dibentuk, disertai dasar-dasar pembenar dari sudut filosofi, yuridis dan sosiologis, termasuk di dalamnya materi muatan apakah yang hendak diatur. Memang tidak semua RUU memerlukan Naskah Akademik. Namun untuk RUU yang berkaitan, antara lain hak dan kewajiban manusia, harus disertai dengan 
Naskah Akademik. Idealnya RUU tentang Ombudsman Nasional pun dilengkapi dengan Naskah Akademik, karena akan berkaitan dengan hak dan kewajiban manusia, yakni hak untuk mendapatkan pelayanan yang maksimal dari aparat penyelenggara negara

Agar tidak terjadi kesalahan serupa, sebaiknya KON berinisiatif serta berbesar hati untuk meninjau ulang RUU yang telah dipersiapkan dan mengadakan harmonisasi serta sinkronisasi dengan berbagai ketentuan serta kelembagaan yang ada. Harmonisasi dan sinkronisasi tersebut diperlukan mengingat perkembangan pesat yang tejadi belakangan ini dan juga dalam upaya mengantisipasi hat-hal yang mungkin terjadi di kemudian hari.

\section{Nilai Pengaturan}

Yang paling penting dari aspek ini adalah bagaimana menempatkan ombudsman secara tepat dalam sistem penyelenggaraan negara, terutama dalam sistem administrasi, di negara yang bersangkutan. Hal ini tidak dapat dielakkan karena pada dasarnya pendirian ombudsman ditujukan untuk memperbaiki pelayanan administrasi negara kepada masyarakat.

DiAustralia ${ }^{62}$, pemikiran mengenai perlunya reformasi di bidang administrasi telah mulai dilakukan melalui diskusi-diskusi akademik pada awal tahun'1960-an. Pada tahun 1968, Pemerintah Federal akhimya membentuk Komite Commonwealth untuk Peninjauan Sistem Administrasi yang diketuai oleh John Kerr, yang kemudian dikenal sebagai Komite Kerr: Pada
1971, Komite ini menghasilkan satu laporan yang merekomendasikan pembentukan a general counsel for grievances (an ombudsman), an administrative review council, an administrative review tribunal, and an administrative procedure statue.

Pemerintah kemudian menindaklanjüti hasil kerja Komite tersebut dengan menerbitkan satu paket UU di bidang Hukum Administrasi Negara, yang terdiri dari:

(1) Administrative Decisions (Judicial Review) Act 1977;

(2) Administrative Appeals Tribunal Act 1975;

(3) Freedom of Information Act 1982;

(4) Pembentukan sebuah Peradilan Federal yang dapat berfungsi lebih cepat dan lebih murah dibandingkan dengan MA;

(5) Ombudsman Act 1976.

Tampaknya pembangunan secara bertahap dan berkesinambungan ini tidak terjadi di Indonesia. KON tidak didirikan di satu ruang yang kosong, melainkan di ruang $\mathrm{di}$ mana telah terdapat beragam ketentuan dan institusi yang bukan tidak mungkin akan saling tumpang tindih, karena di ruang ittu terdapat "ruang abu-abu" ( grey area) yang dapat diklaim oleh institusi yang beragam itu sebagai kewenangan miliknya. Memang tidak mudah untuk membangun suatu sistem secara utuh, namun apabila terdapat kemauan untuk melakukannya maka tidak akan pernah ada kata sulit untuk mewujudkannya.

Tidak ada kata terlambat untuk mulai melakukan pembenahan-pembenahan di bidang Hukum Administrasi Negara, terutama

62 John T.D. Wood, "The Inception \& Development of the Parliamentary Ombudsman: Australia", makalah disampaikan dalam Seminar Good Govemance (Jakarta: Komisi Ombudsman Nasional, 2000), hlm 1-4. 
pembenahan dalam lingkup peraturan dan kelembagaan. Inisiatif seharusnya datang dari Departemen Kehakiman dan HAM, melalui Badan Pembinaan Hukum Nasional (BPHN) untuk mengevaluasi seluruh ketentuan dan kelembagaan di bidang Hukum Administrasi Negara, demi terciptanya dasar-dasar hukum dan kelembagaan yang lebih kokoh dan terbangunnya sinergi antar lembaga dalam upaya memberikan jaminan dan perlindungan yang lebih baik bagi masyarakat.

$\mathrm{Di}$ atas telah disebutkan bahwa ketahanan ombudsman dalam waktu tertentu juga akan berpengaruh terhadap nilai pengaturan. Ketahanan ini dapat ditafsirkan bagaimana ombudsman dapat menghadapi berbagai kendala untuk kemudian survive. Terdapat kondisi-kondisi objektif yang membuat KON mampu bertahan. Kondisi itu antara lain besarnyà dukungan masyarakat dari dalam negeri yang dibuktikan dengan banyaknya jumlah aduan atau keluhan yang disampaikan oleh masyarakat, besarnya dukungan dari masyarakat internasional baik dari organisasi maupun negara-negara asing (International Ombudsman Institute, the Asia Foundation, New Zealand, Australia, Swedia, Belanda, dan lain-lain).

\section{Simpulan}

Mengharapkan hasil maksimal dari suatu lembaga yang dibentuk dalam waktu dua tahun adalah sesuatu hal yang tidak mungkin. Dalam kurun waktu tersebut, KON paling tidak telah menunjukkan keberadaannya sebagai lembaga yáng dapat dipercaya oleh masyarakat untuk menyampaikan keluhan, terutama setelah berbagai saluran yang ada mengalami kebuntuan. Banyaknya aduan yang masuk, paling tidak telah membuktikan hal tersebut. Paparan di atas menunjukkan bahwa di satu sisi KON merupakan lembaga yang mempunyai potensi besar untuk mendorong terciptanya suatu pemerintahan yang baik (good governance) melalui perbaikan administrasi. Namun, di sisi lain harus diakui bahwa efektivitas KON akan banyak dipengaruhi oleh berbagai faktor yaitu hukum, politik, keuangan serta sosial, yang justru sebagian besar berada dalam kekuasaan lembaga legislatif serta eksekutif. 63

Masa depan KON dengan demikian akan ditentukan oleh kemampuannya untuk menghadapi sekaligus menyelesaikan beragam problema yang secara mendasar diperkirakan mampu mempengaruhi keberadaan lembaga ini. KON harus secara sadar bersikap bahwa tidak semua keluhan di bidang kehidupan masyarakat dapat dikerjakan dan bahwa lembaga ini harus berbeda dengan lembagalembaga yang telah ada. Artinya KON tidak dapat bersikukuh untuk "mengeksploitasi semua potensi yang dimandatkan". Realistis akan lebih baik dari utopis. Dan kesemuanya ini membutuhkan konsolidasi serta refleksi mendalam dari lembaga ini sendiri.

${ }^{63}$ Linda C. Reif, "Building Democratic Institutions: The Role of National Human Rights Institution in Good Governance and Human Rights Protection", dalam Harvard Human Rights Joumal, no. 13 Tahun 2000, hlm 68. http://www.lexis.com 


\section{Daftar Pustaka}

Anand, Satya. "Operation of Ombudsman Concept in a Variety of Constitutional Settings." Makalah pada Konferensi Ombudsman Asia Ke-4, Teheran, 1999.

Assegaf, Ibrahim: "Legends of the Fall: An Institutional Analysis of Indonesian Law Enforcement Agencies Combating Comuption." Artikel dalam. Tim Lindsey dan Howard Dick (eds). 2002. Comuption in Asia: Rethinking the Govemance Paradigm, Sydney: The Federation Press, 2002.

Belz, Herman. "A living Constitution or Fundamental Law? : American Constitutionalism in Historical Perspective." Artikel dalam http://www.constitution.org.cmt/ belzicfilintm

Cooray, M.J.A. "Hong Kong's Ombudsman: The First Decade" dalam Linda C. Reif (ed). The Intemational Ombudsman Yearbook Vol. 3 1999, The Hague: Kluwer Law Intemational, 2000.

Elwood, Sir Brian. Speech Notes pada Seminar Good Govemance, Jakarta: Komisi Ombudsman Nasional, 2000.

Fliflet, Ame. "The Ombudsman's Budget, Accounts and Audit - Their Influence on the Ombudsman's Ability to Fulfil His. Responsiblitities" dalam LindaC. Reif(ed). The Intermational Ombudsman Yearbook Vol. 1 1997, The Hague: Kluwer Law Intemational, 1997.

Gellhom, Walter. Ombudsmen and Others: Cifizens' Protector in Nine Countries, Cambridge: Harvard University Press, 1967.
Harian Media Indonesia. Tanggal 14 Juni 2002. Jakarta

Hukumonline. 14 Februari 2002. Jakarta

Jonge, Alice de. “The Pacific Ombudsman's Complaint Function: Comparative Perspectives on Fiji, Papua New Guinea and Vanuatu", 1999, http:///spas.anu.edu.aul melanesia/dejonge.html

Kimwer, Mjemmas G.J. "The Effectiveness of an Executive Ombudsman." Dalam Linda C Reif (ed), The Intemational Ombudsman Anthology, The Hague: Kluwer Law International, 1999:

Komisi Ombudsman Nasional. Laporan Tahunan 2000, Jakarta: Komisi Ombudsman Nasional, 2000.

Lewis, Norman dan Patrick Birkinshaw. When Citizens Complain: Reforming Justice and Administration, Buckingham: Open University Press; 1993.

Manan, Bagir. Lembaga Kepresidenan. Yogyakarta: Gama Media bekejasama dengan Pusat Studi Hukum Universitas Islam Indonesia, 1999.

"Fungsi Ombudsman." Makalah pada Workshop Ombudsman, Surabaya: Universitas Airlangga, 2000.

Manning, Nick dan D.J. Galligan. "Using an Ombudsman to Oversee Public Officials." Working Paper. Prem Notes Public Sector No. 19. The World Bank, 1999, http:I Munw.worldbank.org

McLeod, Ron. "The Role of Ombudsman." Makalah pada Seminar JD Program. Melboume: The University of Melboume, 


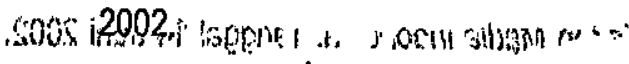

Oosting, Marten. "The Ombudsmain: : R'ole and Development a Comparative Perspective." Makalah pada Seminar The Function of a Parliamentany Ombudsman in a Democratic State, Jakarta, 1999. ."The Ombudsman and His Environment: A Global View." Dalam Linda C. Reif (ed). The Intemational Ombudsman Anthology, The Hague: Kluwer Law Intemational, 1999.

Regan, Anthony J. "Papua New Guinea" dalam Cheryl Saunders \& Graham Hassall (eds). Asia Pacific Constitutional Yearbook 1996, Melbourne: Centre for Comparative Constitutional Studies, 1998.

Reif, Linda C (ed). The Intemational Ombudsman Anthology, The Hague: Kluwer Law intemational, 1999.

. "Building Democratic Institutions: The Role of National Human Rights Institution in Good Govemance and Human Rights Protection." Artikel dalam Hanard Human Rights Joumal No. 13. http://www.lexis.com

Robertson, Sir John. "Setting Up An Ombudsman Office." Dalam Linda C. Reif (ed). The Intemational Ombudsman Yearbook
Vol. 1 1997, The Hague: Kluwer Law International, 1997.

Rowat, Donald C. The Ombudsman: Citizen's Defender, London: George Allen \& Unwin, 1965.

Toronto: The Canadian Publisher, 1973.

Ruzindana, A.. "The Role of the Ombudsman in Enforcing Accountability." Dalam Linda C. Reif (ed.), The Intemational Ombudsman Yearbook Vol. 31999 , The Hague: Kluwer Law Intemational, 2000.

Stacey, Frank. Ombudsman Compared, Oxford: Clarendon Press,1978.

Wayner, Alan J (ed.), Executive Ombudsman in the United States, Berkeley: Institute of Govemmental Studies, 1973.

Wiegand, Shirley A. 1996. " A Just and Lasting Peace: Supplanting Mediation with the Ombuds Model." Artikel dalam Ohio State Joumal on Dispute Resolution No. 12. http://www.lexis.com

Wood, John T.D. 2000. "The Inception \& Development of the Parliamentary Ombudsman: Australia." Makalah pada Seminar Good Governance. Jakarta: Komisi Ombudsman Nasional. 